\title{
Summary of the Study of International Trade Interests from the Point of Value Added Trade
}

\author{
Peng Li \\ Xuchang vocational and technical college $\quad 461000$
}

\begin{abstract}
International trade interest is an important value index to judge a country's participation in international trade activities, under the background of economic globalization, value added trade has become the focus of international trade interest. Compared with the traditional trade statistics law, the research result of international trade interest based on value added trade is more accurate and practical. This paper will discuss the interests of international trade from the perspective of value-added trade, and put forward personal opinions.
\end{abstract}

\section{Introduction}

Since the global economic crisis in 2008 , the state of the world economy is not optimistic, and this has caused considerable impact on China's economy. From 2008 to 2018, after 10 years of development, The "new normal" feature of China's economy is particularly significant, in this context, China's economy entered a transitional period, the state of foreign trade and economic activities in order to eliminate trade barriers, innovation mode of trade, to avoid disputes and promote trade interests as the main target. At the same time, the traditional trade statistics can no longer meet the development requirements of global value chain and cannot accurately calculate the actual benefits of international trade. Therefore, it is necessary to re-examine the benefits of international trade from the perspective of value-added trade. This paper will briefly analyze the development background of international trade interests, discuss the research content of international trade interests from the perspective of value-added trade, and discuss how to solve the problem of international trade interests briefly.

\section{The background of the development of international trade interests}

The interests of international trade in a narrow sense refer to the benefits that a country obtains through participation in foreign trade activities, which mainly involves the improvement of the domestic economic growth index and the quality of life of the people. From the perspective of historical development, as early as the primitive accumulation of capitalism, commercial capitalist doctrine and foreign trade activities have been born, at this stage of the international trade interests mainly refers to the state intervene in the economy directly, prohibit other countries' goods from entering our country, but to encourage the export of domestic traders earned trade wealth [1]. At the same time, in Europe from 16 th century to 18 th century, mercantilism had far-reaching influence and promoted the growth of international trade benefits to some extent. The so-called mercantilism refers to the economic theory and economic policy that influenced Europe from 16 to 18 th century, which advocates that the government should control the national economy and strengthen itself at the expense of the competitive country (the object of foreign trade). Although such a theory has existed long time, the term "mercantilism" was created in 18th century and is widely circulated because of the use of Adam Smith in his 1776 book, The Wealth of Nations. At that time, mercantilism emphasized the holding of gold and silver as the indicators of national wealth and power, thus leading countries in the formulation of trade policies, in order to have precious metals from the trade activities, will be committed to the trade surplus, the intention to trade exports more than the amount of input. This is even more important if a country has no mine or has no access to get minerals. In the case of a trade surplus, it is necessary to use gold or silver to pay the cost of goods and services. The colonies were the export markets and raw materials of their home countries, the policy that had clashed between the European powers and their colonies, such as the American colonies, which provoked resentment against Britain and led to the outbreak of the American War of Independence. In addition, mercantilism favor a large population to provide labor, shoppers and soldiers, and they emphasize thrift and saving as virtues, because they make capital creation possible, so mercantilism can provide an advantageous space for early capitalists' development. But the economist Adam Smith was critical and opposed to mercantilism, in his book The Wealth of Nations, he advocates liberal trade, opposes the state's intervention in the economy, and points out that a personal self-interest is better than a "invisible hand" 
leading to the best benefits. The division of labor as economic growth and international trade interest in the growth of the primary factor in the book. The Wealth of Nations, which was a reaction to the prevailing system of mercantilism, stood at the beginning of classical economics. The Wealth of Nations earned a great reputation for him immediately, and became the most far-reaching of the economic work that had been published finally. Although it regarded as the authoritative book of capitalism, The Wealth of Nations has severely criticized the weakness of unrestrained free enterprise and monopolies. Later, on the basis of The Wealth of Nations, Ricardo put forward Theory of Comparative Advantage, arguing that as long as the goods produced by the country have certain advantages over other countries, they can exchange and gain international trade benefits. In the third volume of Capital, Marx indicated that international trade activities could provide a market for the sale of labors, capital and products for the development of modern industry. The trade between developed and backward countries was unequal, and that the developed countries would use unequal trade to squeeze more benefits, which would surely hurt the interests of backward countries. In 1893, an Italian economist and sociologist, Pareto ,a professor at the University of Lausanne, Switzerland, in his theory of income distribution, used a complex mathematical formula to recall past wealth distribution patterns. In 1903, he proposed the concept of "Pareto Optimality", laid the foundation of modern welfare economics, he believes that in international trade activities, if it is possible to enable at least one country to increase the interests of international trade while keeping other countries at the original level, the distribution of the interests of international trade will not reach the optimal state. By the 21 st century, reversing the trade deficit, strengthening the management of balance, safeguarding the interests of international trade has become the main goal of all countries. Moreover, based on the value added trade perspective, the trade balance refers to the difference between the import and export value of a country's goods and services in a certain period, the balance of trade is a part of the larger economic project Balance Of Payments, which refers to the total amount of all economic transactions between the residents of a country and others. If a country's export value exceeds its import value, the country will have a trade surplus or surplus, otherwise it will have a trade deficit or deficit.
According to the theory of mercantilism economy, trade surpluses are absolutely necessary, but according to classical economics, the full use of economic resources is more important to a country than the trade surplus, however, the idea of a trade deficit has persisted until 20th century and used to developed by protectionist advocates [2].

\section{The research contents of the interests of international trade from the perspective of value added trade}

Based on the value added trade perspective, international trade benefits can be divided into two categories, that is to say cost benefit and product benefit, and the cost benefit refers to the difference between the cost of the domestic production and processing and the cost of the national exchange product. The product benefit refers to the product categories and quantity that the country increases through frequent participation in international trade, and then promotes the use value benefit. Secondly, according to the impact of trade changes, international trade interests can be divided into dynamic trade interests and static trade interests. The so-called "dynamic trade interests" mainly refers to the positive impact that international trade can have on the domestic economic development of the participating Parties. The static trade interest is opposite to the dynamic trade interest, in particular, the foreign trade gains the self-sufficiency under the premise of other conditions unchanged, at the same time, the static trade benefit can be subdivided into the exchange benefit and the division of labor benefit, the exchange benefit is through the exchange to increase the consumption quantity, improve the welfare treatment division of labor benefits through a comparative advantage of the division of labor to optimize resource allocation, reduce costs, access to benefits.

On the other hand, under the background of economic globalization, traditional trade statistics cannot adapt to the development of global value chain, cannot account for the actual interests of international trade accurately, Chinese and foreign scholars also put forward various new methods based on the view of value-added trade, including HIY, KPWW and DRS, Table 1 is based on the value of added trade perspective of the international trade interests calculation method and its contents.

Table 1. The measurement of international trade interests based on value added trade and its contents

\begin{tabular}{|c|l|}
\hline $\begin{array}{l}\text { The method of calculating international trade } \\
\text { interests based on the value added trade } \\
\text { perspective }\end{array}$ & \multicolumn{1}{|c|}{ Contents } \\
\hline HIY & $\begin{array}{l}\text { The HIY method is proposed by Hummels, which refers to the added value of a country's export } \\
\text { to foreign countries and the added value of its export and then again absorbed abroad. }\end{array}$ \\
\hline KPWW & $\begin{array}{l}\text { KPWW law was first proposed by scholar Koopman, this method is based on the background of } \\
\text { economic globalization and value chain, and the National Account accounting system, which is } \\
\text { widely involved in global competitiveness, value chain participation and employment. }\end{array}$ \\
\hline DRS & $\begin{array}{l}\text { The main measure of the DRS method is to study the added value of the intermediate products } \\
\text { which are embedded in one country's export to foreign countries and the final flow of the } \\
\text { products to the country in the form of a product abroad. }\end{array}$ \\
\hline
\end{tabular}


In the scientific accounting of international trade interests, it is necessary to combine the HIY method, the KPWW method and the DRS method to make up the defects of the traditional method of calculation [3].

In addition, under the background of economic globalization, the global value chain has been formed. As early as 1985, Porter, the American economist, described the concept of "value chain" in his book Competitive Advantage for the first time, describing it as "the process and operation of a company to maintain its products by designing, producing, selling and delivering." With the development of the times, the value chain of the ideological connotation is also constantly enriched, in the background of economic globalization, many Chinese enterprises adopt the "Introduction" and "Go out" policy, in the process of business development will build a value chain model, under normal circumstances, enterprise managers will be the value chain mapping into a network or chain-like structure. If the enterprise as the reference point of view, the value chain can be divided into external value chain and internal value chain. The external value chain is composed of horizontal value chain and vertical value chain, the horizontal value chain refers to the value chain from competitors, suppliers and customers, and the vertical value chain refers to the value chain of the industry. In addition, the external value chain is focused on the external activities of the enterprise, such as the relationship between the enterprise and its suppliers and customers (especially from overseas suppliers and customers). The internal value chain consists of various departments of the enterprise and all levels of work, most of the major organizations have procurement department, marketing department, human resources management department, finance department, production department and engineering department, the operation is divided into basic operations and support operations roughly. The so-called "basic work" is divided into four kinds, that is to say enterprise basic operations, human resources management, technical development and procurement operations, support operations have five kinds, namely, internal logistics operations, production operations, foreign logistics operations, marketing operations, after-sales service operations. To protect the interests of international trade, we must strengthen the cooperation between domestic enterprises and overseas enterprises by combining the development rules of global value chain.

\section{How to solve the problems of international trade interests}

\subsection{Enhanced international cooperation through the use of information technology}

In the 21 st century, the advantages of information technology lie in helping enterprises to increase interest index, reduce costs, and maintain an invincible position in the international market. Since the outbreak of the economic crisis, the international market environment is unpredictable, inevitably there will be trade interests. In this respect, domestic enterprises should make full use of information technology to strengthen the company's cooperation with overseas suppliers and customers, and make network overseas marketing plan. The Network overseas Marketing plan under the view of value added trade is to make a comprehensive and orderly arrangement of internet marketing activities under the guidance of Network marketing concept. In order to make the plan, we must make clear the network overseas marketing target, and only the establishment of the goal, can be planned, organized implementation and the overseas marketing activities to make a correct evaluation. Based on the view of added value trade, the goal of networked overseas marketing involves both the hardware target and the software target, in which the hardware target refers to the sales target, the share target, the cost target and the profit target, etc. the software Target is the enterprise management system, customer relationship, price relation, market order and information analysis.These goals are to achieve the hardware objectives of the protection, it can be said that the hardware goal is the result, software objectives is the process, the realization of these two targets can further increase international trade interests.

\subsection{Implement the Belt and Road Initiative, eliminate trade barriers}

The Belt and Road Initiative not only to promote China's capacity output, to ease overcapacity, to inject vitality into China's economy, but also to stimulate the common development of the entire Asian countries [4]. From the macroscopic theory, the Belt and Road Initiative takes the big infrastructure as the core, the capital market dynamics. At present, most of the Asian countries belong to developing countries, especially in Central Asia and South Asia, the level of urbanization is low, industrialization started late, not only need to build large-scale infrastructure, but also faced with funds, energy shortages, backward technology, lack of experience and so on. China has a lot of capacity and capital, and has accumulated valuable technical experience, which is urgently needed by peripheral developing countries, the implementation of the Belt and Road Initiative can achieve mutually beneficial win-win goal, alleviate domestic economic pressure, solve various debt problems, eliminate trade barriers and promote China's trade interests.

\section{Conclusion}

In summary, in line with the development trend of globalization and the improvement of international trade interests, domestic enterprises should attach importance to the cooperation with overseas suppliers and customers by means of information technology, make network overseas marketing plans, implement the Belt and Road, and eliminate trade barriers gradually.

\section{References}

1. Xu Yuan, Zhao Lianlian. Systematic Relationship 
between International Trade, Economic Growth and Environmental Quality -- an Empirical Analysis of China from an Open and Macro Perspective [J]. Economist. 2014(08:1).

2. Zhao Qiuyun, Zhang Jianwu. The Change Trend of China's Labor Income Share and its Driving Mechanism--based on International Trade and Minimum Wage [J]. Journal of Financial Research. 2013(12:2).

3. Zhang Yuan, Wan Guanghua. International Trade and Urbanization in Developing Countries: Evidence from Asia [J]. Social Sciences in China. 2013(11:3).

4. Zhang Liangwei. Cooperation Analysis of International Trade and Logistics under the Strategy of " The Belt and Road "--A Case Study of Guangdong Province [J]. Finance \& Economics. 2015(07:4).

5. Shi Bingzhan. Internet and International Trade--Empirical Analysis based on Bilateral Bi-directional Web Site Link Data [J]. Economic Research Journal. 2016(05:5). 